\title{
11. ORIGIN OF BASALTIC GRAVELLY SANDS, HOLES 410, 410A, 412A, AND 413
}

\author{
William P. Roberts, Department of Geology, James Madison University, Harrisonburg, Virginia
}

\section{INTRODUCTION}

Drilling into basaltic basement in Holes $410,410 \mathrm{~A}$, and $412 \mathrm{~A}$ was terminated owing to jamming of the drill bit. In each instance a gravelly sand consisting mostly of angular to sub-angular fragments of basalt, volcanic glass, and limestone and calcite fragments was recovered from the drill bit or bumper sub. A gravelly sand similar to those described above was also recovered from within basaltic basement in Hole 413, but did not cause the drill bit to stick. In the core-catcher sample from Hole 410, recovered at the contact of the basement with the overylying nannofossil ooze, two thin layers (5 to $10 \mathrm{~cm}$ thick) of well-sorted basaltic sand were interlayered with thin layers $(5$ to $10 \mathrm{~cm}$ thick) of nannofossil ooze.

In Holes 410, 410A, and 413, pieces of basaltic breccia cemented by very pale orange (10YR $8 / 2$ ) to dark yellowish orange (10YR 6/6) micrite were intercalated in the basalt. In each of these holes, the micrite-cemented basaltic breccia or chalk occurs above the basaltic gravelly sands.

Dick et al., 1976, reported basaltic sands and gravels in the lower 90 meters of Hole 396B (Leg 46), in basaltic basement. They examined the mineralogic and textural characteristics of the basaltic sands and gravels, together with the lithology, magnetic inclinations, chemical stratigraphy (based on $\mathrm{TiO}_{2}$ concentrations), and dual induction lateral (conductivity) logs of the basement rock and concluded that the basaltic sands and gravels were natural deposits rather than drilling artifacts. Dick et al. (1976) attributed the fragmentation of the basalts to (1) fragmentation during eruption and cooling or (2) tectonic brecciation after consolidation, or (3) erosion, transportation, and deposition to form talus slopes associated with fault scarps. They were unable to make a clear choice among the three hypotheses. They ruled out the possibility that the sands were formed from "shaving or reaming out" the hole by the drill bit, because no re-entry had been made.

The purpose of this paper is to determine the origin of the micrite-cemented basaltic breccias and the associated basaltic gravelly sands. Special attention will be given to the hypothesis that the gravelly sands may be drilling artifacts derived from the breccias.

\section{METHODS}

Thin sections of eight representative pieces of micrite-cemented basaltic breccia were examined with a petrographic microscope (Table 1). Seven samples of basaltic gravelly sands were sieved at one-half phi intervals (Table 2). Three additional sand samples were sieved: two basalt samples crushed in the laboratory and Sample 410-36, CC.
TABLE 1

Locations of Thin Sections of Micrite-Cemented Basaltic Breccias (Hole-Core-Section, Interval in $\mathrm{cm}$ )

410-26-1, $55-58$

$410-38-11,139-140$

410-39-1, 91-94

410-39-2, 5-7

$410-41-1,24-28$

$410 \mathrm{~A}-2-2,6-8$

$413-1-2,17-20$

413-2-1, 13-20

$413-3-1,53-60$

TABLE 2

Locations of Samples of Basaltic Sands

\begin{tabular}{lrcc}
\hline Hole & Core & Section & cm From Top \\
\hline 410 & 41 & 2 & $88-150$ \\
$410 \mathrm{~A}$ & 6 & Bumper sub & \\
$412 \mathrm{~A}$ & 15 “A” & Core barrel & after jamming \\
$412 \mathrm{~A}$ & 15 "B" & Core barrel & after jamming \\
413 & 1 & 1 & $10-13$ \\
413 & 1 & 1 & $100-102$ \\
410 & 36 & $\mathrm{CC}$ & \\
\hline
\end{tabular}

The size distributions of the basaltic sands were tested for their similarities to the theoretical size distribution of crushed particles according to the Rosin-Rammler Law (Rosin et al., 1933) by plotting the sieve results on graph paper with a scale of iterated logarithm as ordinate and logarithm as abscissa. According the the Rosin-Rammler Law, the iterated logarithm of the mass of crushed particles larger than a certain size ("oversize" weight), plotted against the logarithms of the sieve openings $(\mathrm{mm})$, will be a straight line (Herdan, 1960). The Rosin-Ramler Law has been applied most often in studies of the size distribution of broken coals (Landers and Reid, 1946) (Figure 1), but has also been found applicable to glass, gypsum, cement, quartz, clay, and many other natural and artificial materials (Herdan, 1960).

After the basaltic sands were sieved, the following studies were conducted:

1) binocular estimation of the composition of coarse fractions $(>177 \mu \mathrm{m})$;

2) petrographic microscope determination of grain mounts of fine fractions $(>63 \mu \mathrm{m}<177 \mu \mathrm{m})$. Using the mechanical stage, 100 non-opaque grains were identified (Krumbein and Tukey, 1956);

3) roundness estimation of the modal size class and the two finest sieve fractions of each sample by comparison with the Powers Roundness Scale (Powers, 1953). The results of three independent operators were averaged. 


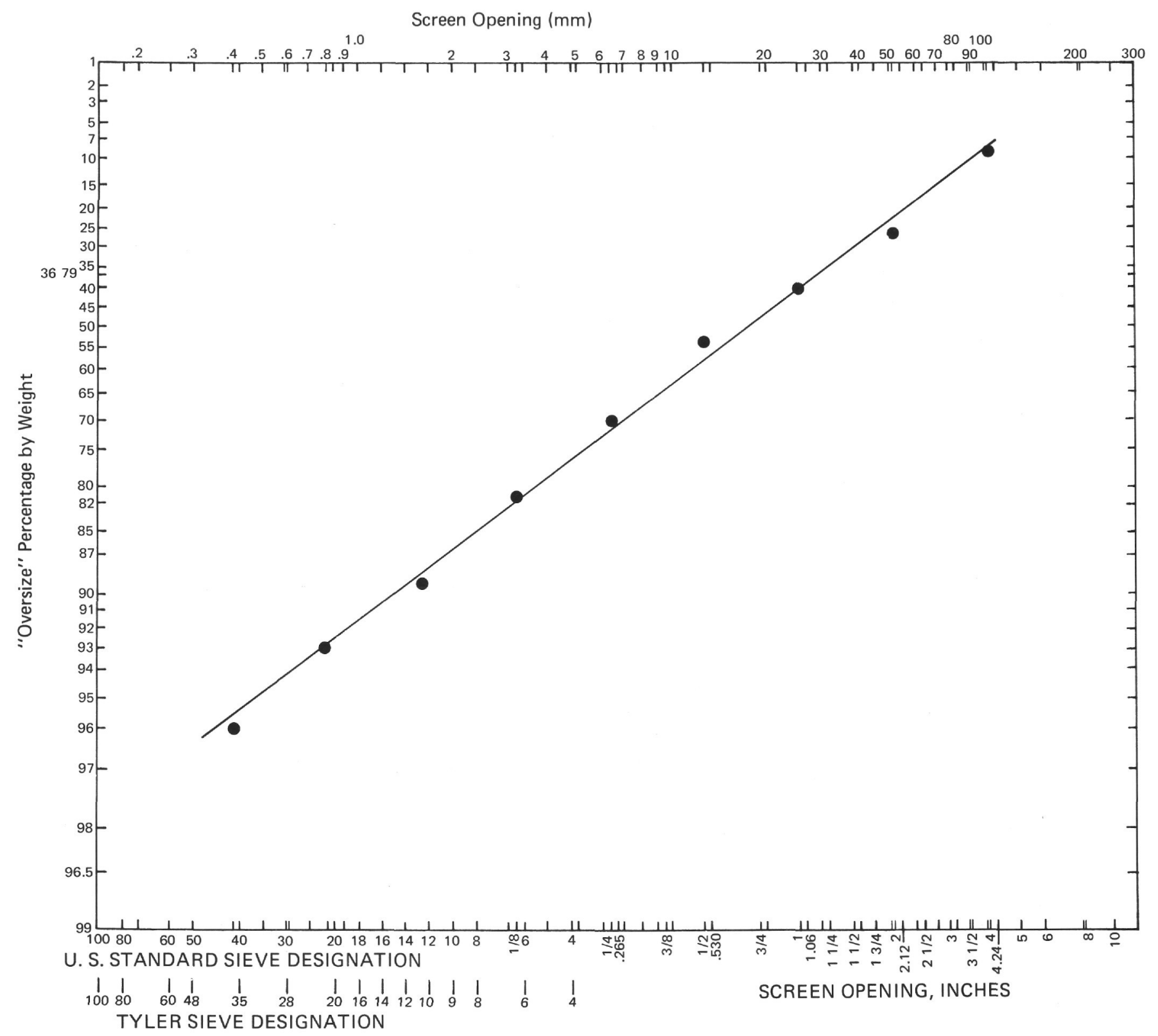

Figure 1. Size distribution of broken coal (modified after Landers and Reid, 1946, fig. 1).

\section{RESULTS}

\section{Petrography of Micrite-Cemented Basaltic Breccias}

The micrite-cemented basaltic breccias consist of roughly equal proportions of the following two major constituents:

1) Basalt clasts - a mosaic of plagioclase spherulites and rare olivine crystals in a black to dark brown or yellowish brown (when palagonitized) glass. The clasts are equant to elongated, angular to sub-angular, and range in diameter between $1 \mathrm{~mm}$ to $3 \mathrm{~cm}$. The clast size is the only major difference in this constituent between the samples.

2) Micrite matrix - gray to yellowish orange microcrystalline calcite with scattered foraminifers and rare diatom and radiolarian fragments. Thin veinlets of clear calcite $(0.3$ to $0.5 \mathrm{~mm}$ thick) occur in intersecting patterns. Sub-angular to sub-rounded intraclasts up to $5 \mathrm{~mm}$ long occur near the boundaries of the micrite and basalt clasts. In some areas, the intraclasts are cemented by sparry calcite. Rare angular cavities about $0.5 \mathrm{~mm}$ in diameter, some with yellowish (palagonitized ?) rims, that may have originally been glass clasts, occur in the micrite.

\section{Basaltic Sands and Gravels}

\section{Grain Size}

The sieve results plotted on "Rosin-Rammler" graph paper show that the samples plot as either nearly straight lines, two straight-line segments, or three straight-line segments (Table 3, Figure 2). Owing to overlap of the plots, only 5 of the 10 samples are plotted (Table 4, Figure 2). The plots that overlap very closely are: samples " $A$ " and " $B$ " of Core 412A-15; the two samples of basalt crushed in the 
TABLE 3

Shape of Size Distribution Plots of Basaltic Gravelly Sands

\begin{tabular}{cl}
\hline Shape of Plot & \multicolumn{1}{c}{ Samples } \\
\hline Nearly straight line & $410-36, \mathrm{CC}$ \\
& $412 \mathrm{~A}-15$ "A" \\
& $412 \mathrm{~A}-15$ "B" \\
Two straight-line & $413-1-1,10 \mathrm{~cm}$ \\
segments & Crushed basalt 1 \\
& Crushed basalt 2 \\
Three straight-line & $410 \mathrm{~A}-6 \quad 413-1-1,100 \mathrm{~cm}$ \\
segments & $413-1-1 \quad 412 \mathrm{~A}-13-1$ \\
\hline
\end{tabular}

laboratory; and samples from Core 410A-6, Sections 413-1-1 and 412A-13-1, and Sample 413-1-1, $100 \mathrm{~cm}$.

Most of the basaltic sand samples are well sorted, but one sample, 412A-15 " $\mathrm{B}$ " is poorly sorted (Table 5 ). The two crushed basalt samples are poorly sorted. The layered basaltic sand of Sample 410-36, CC is very well sorted. The mean grain size varies from $-1.66 \phi$ to $2.97 \phi$ (Table 5).

\section{Roundness}

The basaltic sand samples consist of predominantly angular to sub-rounded particles (Table 6). The layered basaltic sand (Sample 410-36, CC) is mostly sub-angular to

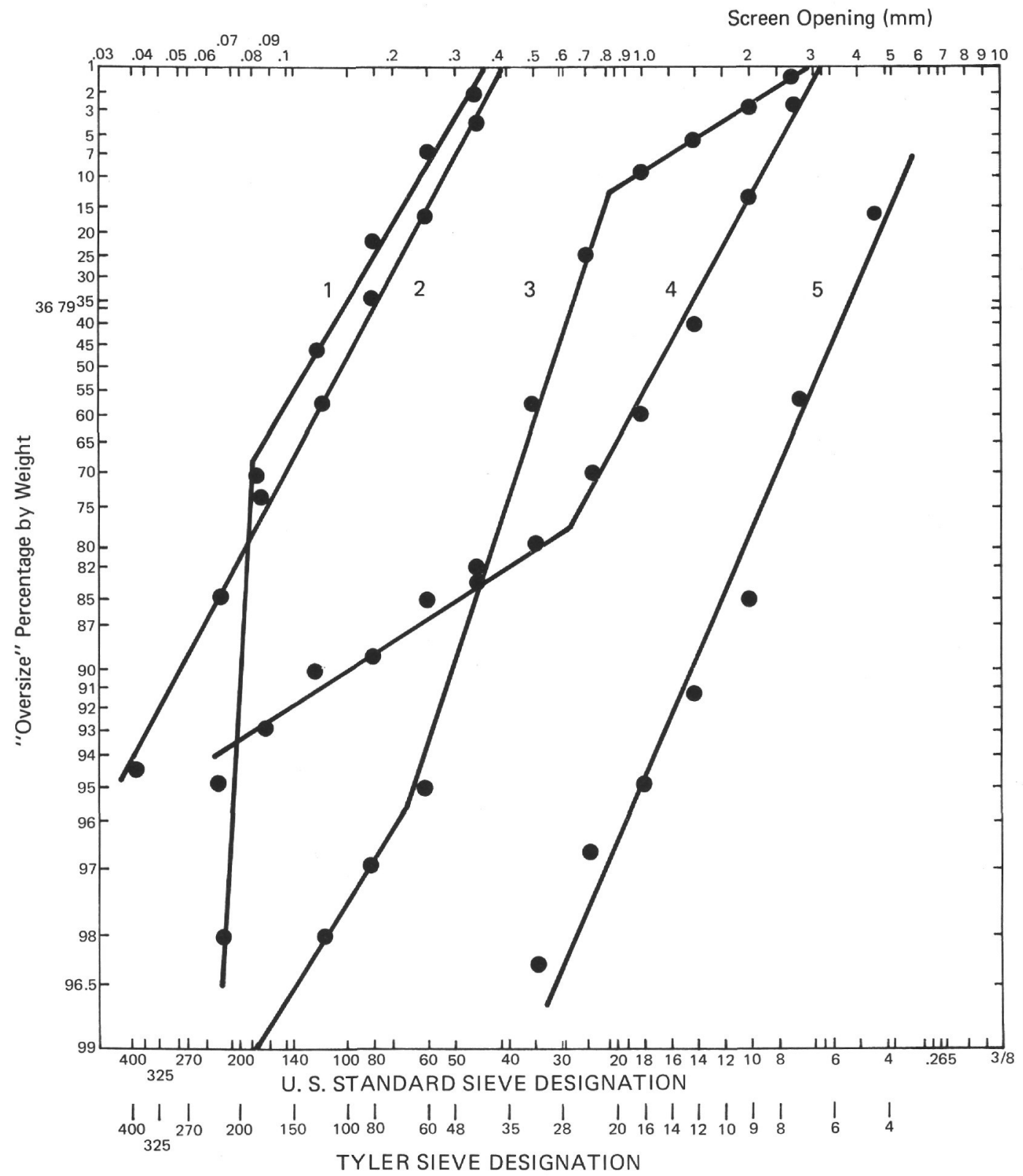

Figure 2. Size distribution of basaltic gravelly sands. (See Table 4 for key to numbers next to plate.) 
TABLE 4

Key for Sample Numbers on Graph

\begin{tabular}{cc}
\hline $\begin{array}{c}\text { Numbers on } \\
\text { Graph }\end{array}$ & $\begin{array}{c}\text { Sample } \\
\text { (Interval in cm) }\end{array}$ \\
\hline 1 & $413-1-1,10-13$ \\
2 & $410-36$, CC \\
3 & $412 \mathrm{~A}-13-1$ \\
4 & Crushed basalt \\
5 & $412 \mathrm{~A}-15$ \\
\hline
\end{tabular}

TABLE 5

Sorting Values of Basaltic Sands and Gravels

\begin{tabular}{lccl}
\hline \multicolumn{1}{c}{ Sample } & $\mathrm{M}_{\mathrm{Z}}(\phi)^{\mathrm{a}}$ & $\sigma_{\mathrm{I}}(\phi)^{\mathrm{b}}$ & \multicolumn{1}{c}{$\begin{array}{c}\text { Sorting } \\
\text { Classification }\end{array}$} \\
\hline 410A-6 & .63 & 0.66 & Moderately well sorted \\
413-1-1 & 1.0 & 0.72 & Moderately sorted \\
412A-15-A & -1.66 & 0.65 & Moderately well sorted \\
412A-15-B & -1.63 & 1.5 & Poorly sorted \\
412A-13-1 & 0.87 & 0.68 & Moderately well sorted \\
413-1-1, 100-102 cm & 0.93 & 0.80 & Moderately sorted \\
413-1-1, 10-13 cm & 2.97 & 0.65 & Moderately well sorted \\
410-36, CC & 2.92 & 0.17 & Very well sorted \\
Basalt 1 & 0.67 & 1.64 & Poorly sorted \\
Basalt 2 & 0.20 & 1.50 & Poorly sorted \\
\hline
\end{tabular}

${ }^{\mathrm{a}}$ Graphic mean (Folk, 1968).

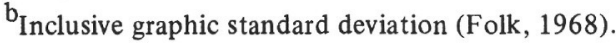

${ }^{\mathrm{c}}$ Folk (1968)

TABLE 6

Roundness of Basaltic Sands and Gravels

\begin{tabular}{ccccccc}
\hline $\begin{array}{c}\text { Size } \\
\begin{array}{c}\text { Fraction } \\
(\mu \mathrm{m})\end{array}\end{array}$ & $\begin{array}{c}\text { Very } \\
\text { Angular } \\
(\%)\end{array}$ & $\begin{array}{c}\text { Angular } \\
(\%)\end{array}$ & $\begin{array}{c}\text { Sub- } \\
\text { Angular } \\
(\%)\end{array}$ & $\begin{array}{c}\text { Sub- } \\
\text { Rounded } \\
(\%)\end{array}$ & $\begin{array}{c}\text { Wounded } \\
(\%)\end{array}$ & $\begin{array}{c}\text { Well- } \\
\text { Round ed } \\
(\%)\end{array}$ \\
\hline$>88<125$ & 1.0 & 20.5 & 41.0 & 31.8 & 4.7 & 1.0 \\
$>63<88$ & 1.3 & 19.5 & 42.3 & 28.6 & 7.0 & 1.3 \\
Modal sizes & 2.6 & 20.9 & 62.7 & 13.8 & 0 & 0 \\
\hline
\end{tabular}

angular (Table 7). The few rounded particles are calcite spherules or foraminifers. The crushed basalt samples are very angular to angular (Table 8 ).

\section{Composition}

The coarse size fraction ( $>177 \mu \mathrm{m}$ ) is mostly brownish, angular chips of volcanic glass and angular to sub-angular basaltic clasts. Almost all the glass is very fresh, but some appears to be partially palagonitized. Small amounts of calcite spherules, yellowish micrite clasts, and abraded foraminifers also occur.

The finer size fractions ( $>63 \mu \mathrm{m}$ to $<177 \mu \mathrm{m}$ ) are composed mostly of calcite and altered grains (Table 9). The altered grains, although unidentifiable, are probably mostly basalt fragments, micrite, or possibly some altered glass. Small amounts of broken or abraded foraminifers are included as "calcite." Palagonite and fresh volcanic glass, and small amounts of broken olivine and plagioclase crystals occur (Table 9).

\section{Origin of the Basaltic Gravelly Sands}

Three major types of evidence suggest that most of the basaltic sands recovered from Holes 410, 410A, 412A, and 413 are drill cuttings:
TABLE 7

Roundness of Core 410-36

\begin{tabular}{lcccccc}
\hline $\begin{array}{c}\text { Size } \\
\text { Fraction } \\
(\mu \mathrm{m})\end{array}$ & $\begin{array}{c}\text { Very } \\
\text { Angular } \\
(\%)\end{array}$ & $\begin{array}{c}\text { Angular } \\
(\%)\end{array}$ & $\begin{array}{c}\text { Sub- } \\
\text { Angular } \\
(\%)\end{array}$ & $\begin{array}{c}\text { Sub- } \\
\text { Rounded } \\
(\%)\end{array}$ & $\begin{array}{c}\text { Wounded } \\
(\%)\end{array}$ & $\begin{array}{c}\text { Well- } \\
(\%)\end{array}$ \\
\hline$>88<125$ & 4 & 36 & 55 & 5 & 0 & 0 \\
$\begin{array}{l}\text { Mode }) \\
>63<88\end{array}$ & 2 & 33 & 59 & 5 & 1 & 0 \\
\hline
\end{tabular}

TABLE 8

Crushed Basalt Samples

\begin{tabular}{lcccccc}
\hline $\begin{array}{c}\text { Size } \\
\text { Fraction } \\
(\mu \mathrm{m})\end{array}$ & $\begin{array}{c}\text { Very } \\
\text { Angular } \\
(\%)\end{array}$ & $\begin{array}{c}\text { Angular } \\
(\%)\end{array}$ & $\begin{array}{c}\text { Sub- } \\
\text { Angular } \\
(\%)\end{array}$ & $\begin{array}{c}\text { Sub- } \\
\text { Rounded } \\
(\%)\end{array}$ & $\begin{array}{c}\text { Wounded } \\
(\%)\end{array}$ & $\begin{array}{c}\text { Rounded } \\
(\%)\end{array}$ \\
\hline$>88<125$ & 78 & 22 & 0 & 0 & 0 & 0 \\
$>63<88$ & 30 & 59 & 11 & 0 & 0 & 0 \\
Modal sizes & 100 & & & & & \\
\hline
\end{tabular}

TABLE 9

Averages Composition of Fine Size Fractions of Basaltic Sands and Gravels (\%)

\begin{tabular}{lcccccccc}
\hline $\begin{array}{c}\text { Size } \\
\begin{array}{c}\text { Fraction } \\
(\mu \mathrm{m})\end{array}\end{array}$ & Opaque & \multicolumn{1}{c}{ Nonopaque Calcite } & Altered & Palagonite & Glass & Olivine & Plagioclase \\
\hline$>125<177$ & 13.3 & 86.7 & 21.5 & 64.3 & 8.3 & 2.5 & 2.7 & 0.7 \\
$>88<125$ & 11.3 & 88.7 & 29.4 & 54.7 & 8.8 & 3.3 & 2.5 & 1.2 \\
$>63<88$ & 8.3 & 91.7 & 39.2 & 45.1 & 8.6 & 3.4 & 2.9 & 0.9 \\
\hline
\end{tabular}

1) the fragments of basalt, glass, yellowish micrite, along with crystals of olivine and plagioclase that are major constituents of the basaltic sands, appear to be identical in composition, color, and texture to the same constituents of the basaltic breccias;

2) the basaltic sands, except Sample 410-36, CC, were recovered either stratigraphically below or mixed with pieces of basaltic breccia;

3) the size distributions of the basaltic sands approach straight-line plots on "Rosin-Rammler" graph paper.

It seems especially significant that the sands were recovered only after coring the basalt and that the composition and texture of the sands are nearly identical to the breccias. Drilling through any type of rock might logically be expected to produce drill cuttings with a composition similar to the rock being drilled. If the rock matrix is brittle and tends to have conchoidal fracture, as micrites do, then enough drill cuttings might be produced to finally jam the drill bit.

Although Dick et al. (1976) mention the presence of "pieces of calcite-cemented microbreccia" in the sands from Hole 396B, they seem to attach no significance to that evidence. It does not seem logical that the fragmentation of a cooling basalt flow or the erosion and deposition of a basaltic talus would result in the presence in the basaltic sands of clasts of micrite identical in texture, color, and composition to a basaltic breccia found stratigraphically above the sand, indicating deposition after the sand. Similarly, it would seem that tectonic brecciation would result in a sand similar in composition to the rock below rather than above.

Some of the size distribution plots of the sands approach the straight-line plot on "Rosin-Rammler" graph paper. 
Two notable exceptions, however, significantly weaken the credibility of this evidence. These exceptions are the almost perfect straight-line plot of Sample 410-36, CC and the bent-line plot of the basalts crushed in the laboratory (Figure 2). The interlayering of the basaltic sands of Sample 410-36, CC with thin layers of nannofossil ooze, along with the fine grain size and very good sorting (Table 5) are strong evidence that the sands of Sample 410-36, CC are natural deposits. A slight grading was reported in the core description for the basaltic sand layers. These sands may be turbidites or accretionary sediment deposits from a current. The samples of basalt crushed in the laboratory would be expected to have straight-line size distributions; instead they have two nearly straight-line segments.

\section{SUMMARY AND CONCLUSIONS}

The basaltic gravelly sands are probably drilling artifacts formed as a result of drilling into the brittle micrite-cemented basaltic breccias above the sands. Sample 410-36, CC, with its layered nature, its fine, well-sorted texture, and its position immediately above the basement, is the exception to the above conclusion. This fine to very fine sand is apparently either an accretionary sediment deposit or a turbidite.

It should be noted that, in view of the small number of samples studied, and the widespread locations of the drill sites, the conclusions reached in this paper are tentative. Many more samples from several drill sites in a small area would be needed to verify the above conclusions.

\section{ACKNOWLEDGMENTS}

We wish to thank Captain J.C. Clark and the crew of the Glomar Challenger, for supplying major equipment and services. The laboratory work of David Collins and Jay Rhoderick, of James Madison University, is greatly appreciated. Henry Dick and David Poché critically read the manuscript.

\section{REFERENCES}

Dick, H., et al., 1976. Glass-rich basaltic sand and gravel within the oceanic crust at $22^{\circ} \mathrm{N}$, Nature, v. 262, p. 768-770.

Folk, R.L., 1968. Petrology of sedimentary rocks: Austin (Hemphills).

Herdan, G., 1960. Small particle statistics: London (Butterworths).

Krumbein, W.C., and Tukey, J.W., 1956. Multivariate analysis of mineralogic, lithologic and chemical composition of rock-bodies, Journal of Sedimentary Petrology, v.26, p. 322-337.

Landers, W.S., and Reid, W.T., 1946. A graphical form for applying the Rosin and Rammler equation to the size distribution of broken coal, Bureau of Mines Information Circular 7246: Washington (United States Department of the Interior).

Powers, M.C., 1953. A new roundness scale for sedimentary particles, Journal of Sedimentary Petrology, v.23, p. 117-119.

Rosin, P., and Rammler, E., 1933. The laws governing the fineness of powdered coal, Journal of the Institute of Fuel, v.7, p. 29 . 